\title{
Abai and Firdowsi
}

\section{Seied Mohammad Bagher Kamaladdini}

\author{
Department of Persian Literature and Language, Payame Noor University, Tehran, Iran \\ E-mail address: kamaladdini@pnu.ac.ir
}

\section{Keywords: Abay; Kazakhhstan; influence; Persian poetry; Ferdowsi}

\section{ABSTRACT}

Abay Qunanbaev (Qunanbaiuli) was the founder and architect of Kazakh written literature. Since his childhood, he studied religious science and got acquainted with eastern literature, particularly Iranian classic literature and Persian poetry and poets such as Ferdowsi, Hafiz, Sa'adi, Molavi, Nezami and etc.

Abay read epic poetry and odes from the great eastern poets on their original texts or Jugatay (old language of central Asia) translations and first raised prosody derived from Persian poetry in Kazakh poetry and this way many Persian vocabulary entered Kazakh language.

Using a bibliographic method, the author in current research studies this Kazakh poet's works from valid and reliable resources. Regarding the special attention paid by this poet to the existing concepts in Persian poetry, particularly those of Ferdowsi, we have attempted to express some of their similarities.

\section{INTRODUCTION}

Kazakhs are the most perennial nation with the greatest territory among contemporary Turks. Kazakh language like Kyrgys, Tatar and Bashqir languages belongs to Qbchaqy branch of central Turkey or Ural-Altay languages. It is a subgroup of Qbchaq-Nogai sharing many common features with Kyrgyz-Turkish language. Languages with close affinity with Kazakh language include Nogai and Karakalpak dialects. Kazakh dialects show little variety. Linguists consider Kazakh language integrated. Its vocabularies are originally Turkish but there are a number of Arabic, Russian and Persian vocabularies in this language. In terms of phonology (morphology), Kazakh language like other Turkish language branches belongs to agglutinative (synthetic) and inflected languages and in terms phonetics is based on consistency rules. Kazakhh language has passed several periods and possesses rich literature in both oral and written form (heath, page 6, Saleh Abolhasani, page 21; Mokhtar Moghavin pages 5,6)

\section{ABAY, THE GREATEST KAZAKH POET}

Ibrahim Qunanbaev-Abay- was born in 1845, Tubikti tribe in Chingis Mountains, Semey area in Kazakhstan. His father, Qunanbai (Bai means Khan) was a Kazakh nobleman and the governor of his own area. He was a religious person who never let anyone violate Islamic principles and customs. Abay's mother named him "Abay" meaning thoughtful and smart.

From his childhood, with the help of his grandmother, he got familiar with Kazakh fictions, stories and oral literature most of which were in verse (poetic). He gradually got interested in poetry so that over a short time he memorized hundreds of verses from traditions before him and epic and romance stories he had heard from his grandmother. He began his elementary studies with private teachers at home and entered AhmadReza school in Semey city when he was 10. The majority of teachers in this school were Tatars graduated from Bokhara, Samarqand, Turkistan, Qazan, Ofa and other cities who taught Quran science, tradition, geography, history, Turkish and Persian literature. As a student at this school, Abay knew Arabic, Turkish and Russian language and literature. After 3 years of studies, he returned to his hometown and eagerly studied vernacular Kazakh culture and 
literature. He expressed his poetic talent using works from great eastern poets including Fozuli, Navayi, Mulavi, Sa'adi, Hafiz, Nizami, Ferdowsi and folklore Kazakh literature and considered ethical and social contents from a new standpoint. In addition to familiarity with Persian literature, he began versifying lyrics and learned to play Dambare (famous Kazakh Dutar). He was religious and did not separate religion from Kazakh people's life and frequently used Islamic interpretations such as Allah, the holy prophet, religion, faith, Muslim etc., in his verses. He first proposed prosody in Kazakh poetry. As such many Persian words entered Kazakh language. Abay's poetries included couplets, quatrain, ode, love poem and marai among which the latter did not exist in Kazakh poetry before Abay. He was the first Kazakh poet who used a lot of Persian vocabularies in his verse. The contents of Ferdowsi's Shahnameh and Nizami's Khamseh were introduced to Kazakh people by Abay.

Abay represented Kazakh Realistic literature during the $19^{\text {th }}$ century. The main feature of his peom is his attention to the surrounding identities. With an impressive language, he realistically describes the nature, people and their ordinary behaviors, common issues and social and political problems. He also states conditions of different social classes including the poor and the rich during different seasons, criticizes the rich people for their avarice for materialism and expresses his hatred towards sycophancy of subjects to foreign masters. He wished Kazakh youth learned new techniques and science while relying on their own culture and protecting their religious beliefs and faith to serve people other than seeking for positions and ranks to be exploited by colonists (Shadkam, ps. 5-9, Heyat, p. 346; Abolhasani, p. 41).

\section{Abay and eastern literature}

Abay first knew eastern literature in Ahmadreza school and affected by eastern poets he began composing verses. He had a respectful relationship with eastern classical literature and was inspired by masters of Persian poetry. We observe the influence of the holy Quran, Persian poets and "one thousand and one nights" story on Abay's eastern school so that he was affected by "one thousand and one story" and wrote a story titled "Azam (the greater) which was a new genre in Kazakh literature. He was quietly acquainted with stories such as "Joseph and Zoleikha", "Tooti Nameh", "Khosrow and Shirin", "Leili and Majnoon", "Eskandar Nameh" and books such as "Qabus Nameh", "Shahnameh by Ferdowsi", "Golestan and Boostan by Saadi", " Beihaqi's history", "Tabari's history" and "Jami-o-Tavarikh (comprehensive history)" and well utilized them.

\section{Abay's works}

His works include poetry, stories, letter of advice, translations, articles and letters.

Abay's poetry entails ethical, social and political issues and he has published some of them with pseudonyms in local newspapers (Abay's complete poetical work;1995). Abay wrote four stories, three of which were affected by eastern literature. His famous story is "Alexander" the content of which is derived from Ferdowsi and Nizami. Another story is "Masoud" based on Arabic stories. Another story is "Azam" which is similar to one story in "one thousand and one nights". Finally, the last story is "Vadim" derived and translated from the incomplete novel by Lormentov.

Abay's letter of advice includes philosophical and scientific beliefs and thoughts composed of 45 pieces of advice in the form of stories each with a different content. It is a reflection of his poetry in which his beliefs and thoughts about the universe, afterworld, faith, prayers, philosophy, logic, wisdom, God and love in Him are stated with simple and fluent verses. Except incomplete translation of Lormentov's novel, he translated his poems into Kazakh language. He also translated "Eugene Onegin" a novel in verse by Alexander Pushkin- famous Russian poet- and poetic pieces from Shchedrin and Krylov including allegories and love poems into Kazakh language in 1889 and introduced some poetries versified by Byron, Goethe and Schiller through Russian language to Kazakh people. It is worthy of mention that the aforementioned translations were in verses in which footprints of eastern morale is more or less tangible in conveying the contents. Abay also has written some articles on Kazakh tribes history and some letters to his friends, relatives and government of the time. 


\section{Abay and Ferdowsi}

Among Kazakhs, Abay was the first one who broadly considered eastern culture. When he was studying at Ahmadreza School in Semey, he got familiar with works of Persian, Arabic and Turkish poets and as he grew older, he turned over pages of poetic works among whom he was mostly affected by Ferdowsi. There are a lot of thought similarities between Shahnameh by Ferdowsi and Abay's masterpieces. He knew translations of Shahnameh in prose and verse in Turkish languages. He has used the names of heroes, armaments, words and collocations from Shahnameh among which we can refer to the following pieces:

Translation: I'm wearing war shield and armor but it is squeezing my body. Although arrow and sword are not effective, I wish I went to war with my own horse.

Translation: Terek (a river in Caucasia leading to Caspian Sea) is stubborn, boiling and roaring, cracking the rocks and mountains to make a way. Its meandrous waves are like a lion's mane twisting like a dragon.

Translation: malicious deceiver resorts to trickery and pretends as a sincere friend.

Translation: he was well-known among Muslims like Alexander, Timur and Changiz Khan (Abay, p.112)

Abay also narrates with a beautiful allusion the story of Toos's death who was lost in blizzard and was never back:

Translation: I saw with my eyes a high pine tree fallen putting its head on the ground. Its leaves were yellow in the agony of death. Who listens to its mourning? (Abay, p.106)

In his prose, Abay calls his compatriots upon knowledge acquisition and orders them to learn other languages other than their native one such as arabic, Persian and Russian:

We must evolve and develop and promote our treasures with interest. This is the food of soul. Soul is superior to body. The body has to bow down against the soul (Abay, p.103)

"The hereafter and the world do not exist without knowledge. The prayers we say or our fasting or Haj and other worships would not be accepted without knowledge" (Abay, p.107).

Abay considers faith and knowledge acquisition as prerequisites for true worship and advises on its serious acquisition:

Translation: don't think of your profit but care about good name. Try to acquire more knowledge and be indefatigable in studies. More knowledge is latent in books (Abay, p.105).

In every piece of Shahnameh, Ferdowsi recites the importance and value of knowledge as we read in the primary literature:

The wise is the mighty knowledge make the elderly's heart young

Knowledge and religion lead you to truth you have to seek for salvation

(Ferdowsi, vol. 1, pages 13 and 18)

In Abay's religious thought, lying, backbiting, self-praise, prodigality and laziness (selfindulgence) are five enemies for human being:

Translation: know that lying, backbiting, self-praise, laziness, prodigality are your enemies.

In contrast, there are five humane and noble characteristics to which people are advised:

Translation: knowledge desire, efforts, deep thinking, contentment and mercy. Think of them. They are good deeds if you submit to them.

Abay and Ferdowsi both call people upon strife and struggle to supply their material and spiritual needs and warn them about temporariness of this transient world. They believe that man must set out with the necessary provisions as much as necessary because he is born to die. Abay says:

Translation: I saw human beings as dogs eating each other's flesh. This world bears no delight for a thoughtful man. Most people have a nice figure but a bad character.

Translation: though man is human being today, he will be earth tomorrow. But today world with its luxury deceives him. Do you know where you will be tomorrow? You are created to die, dear. 
Translation: thought and sagacity serve as a castle for man. Poverty is the worst problem in this world. Lo, the youth, don't be joyful at this and that because these short days are an assessment field (Abay, p.66)

Although Abay notifies Kazakh people about unreliability of the world, he says that these people do not have a hearing ear. They are all materialist and greedy. He states in his speech: "if you ask a Kazakh about his grief, you will find the answer in his proverbs". "If you are going to live half-day, collect money for one day". "If you are poor, your father is a stranger, too." "Property is the dear child of man". "Be hateful of an uncharitable people". "It is clear that Kazakh does not grieve for well-being, knowledge, literacy and justice but he/she grieves for wealth." (Abay, vol.2, p.101). Or he says in a piece:

Translation: a materialist person has no friend other than his wealth. He has no alternatives except deceit. As he is permanently thinking of his earning, they are always worried. He gives nothing to other except his leftover (Abay, p.56).

Negligence of death and fate is the subject to which both poets have referred. Abay blames negligence of death and fate and likens it to drunkenness:

Translation: he sat so long and got up to say. I can still hear his voice asking "what do you do with fate? Engage in laughter and play to the end of life (Abay, p.51).

Ferdowsi also refers to the resurrection, death, fate and the future life in Shahnameh and wakens man from negligence:

He said be careful that only death is born

(Ferdowsi, vol.1, p56)

Among other religious thoughts of Abay we can refer to worshiping and prayers which console human heart and spirit and are the best factor for reinforcing spiritual relationship with eternal Deity:

Translation: prayer creates a joyful force and consoles the sorrowful heart. Prayer is sweet wording that man can not understand. The order "be quiet" is heard. Prayer relieves you by which grudge is removed and forgotten.

In these verses, Abay was inspired by this Quran's verse: indeed, praise of God consoles hearts (Surah Raad, verse 28). This idea reminds us Rostam's prayers in fight with Sohrab. Ferdowsi portraits absolute poverty and absolute richness in a beautiful representation:

I heard Rostam got his energy and force from God from the very beginning

(Ferdowsi, vol.2, pages 255, 256)

In prayers and beseeching, Ferdowsi is a wise literary man who recites his prayers in specific customs. In introductions to prayers and requests of story characters, he illustrates the most sublime theological contents and divine beauty and praises God: (Choobineh, p259) as we read in the battle between Keykhosrow and Afrasiyab:

From the position of the world kingdom he came to the creater

He left his army people to say prayers and told his secrets to the Lord of the world

(Ferdowsi, vol.5, pages 312, 313)

In using the folklore, maxims and proverbs, Abay was affected by eastern literature to some of which we refer here:

Translation: with horse and tidy clothing, great boast little toast he looks for a party and food.

Translation: the clock is the same thief who makes you negligent of life with its Tic-Tac. Time is mute, unstable and restless which never goes back reminding this proverb: the lost prestige is not regained.

Translation: the materialist person collects wealth to be boastful of and annoys people with his ostentation. He is a pig and assumes others dogs. He wants to make friend with pottage and bones.

Translation: I grew up a puppy to be a dog but it tore my leg. I taught someone shooting, but he shot at me, synonym with this proverb: growing snakes in the grass. (Abay, p.48)

Finally, both poets considered elegizing for the dead child. In 1859, Abay lost his son "Abdal-Rahman" who was his most educated and talented child and was only 27 . This sorrowful event 
affected Abay, significantly. He composed lots of verses with crying eyes to this respect to console his spirit grief.

He also wrote a mourning letter about Abd-Al-Rahman and another about his other child "Akimbay.

We also encounter such elegizing in Shahnameh after the death of a hero on the part of the living ones, the best of which are the elegies by Rostam and Tahmineh for their son's death, Sohrab.

Rostam got off the horse very promptly putting his head on the ground

He mourned "thou fighting man proud and son of a hero

Sun and moon wont see like you neither armor nor bed nor crown and hat

What happened to me that I killed a young man for the elderlies of the house

(Ferdowsi, vol. 2, pages 243,244)

\section{CONCLUSION}

Abay, the greatest Kazakh poet paid a special attention to eastern literary works specially those of Persian poets and writers. He praised mostly Ferdowsi and his Shahnameh so that many contents and subjects from Shahnameh exist in his works.

\section{References}

a) Persian references

The holy Quran

[1] Abolhasani, Saleh, Republic of Kazakhstan, publication center of foreign ministry, first edition, Tehran 1997

[2] Joveyni, Aziz-Allah, Shahnameh, from handwritten texts from Florence museum, University of Tehran publications, 1999

[3] Choobineh, Sajad, theoretical and practical wisdom in Ferdowsi's shahnameh, Navide Shiraz, first edition, Shiraz 1999

[4] Shadkam, Haj Mohammad, Abay the great Kazakh poet, Makhtoom Gholi Faraghi cultural and publication institute, Gorgan, 1999

[5] Heyat, Javad, an introduction to Turkish language and dialects, Peykan publications, vol.3, Tehran 2001

b) Kazakh references

[1] Moghavin, Mokhtar, poetry of five ages, Jazooshi publication, 2 volumes, Bina 1991

[2] Abay's complete poetry, 2 volumes, Almaty 1995 